\title{
消石灰添加が豚䔬堆肥の電気伝導度ならびに ミネラル溶出率に及ぼす影響
}

\author{
高橋正宏 ${ }^{a}$ 梅本英之 ${ }^{1}$ \\ 石川県畜産総合センター，石川県押水町 929-1325 \\ 1石川県農業総合研究センター，金沢市 920-3198
}

(2004. 11. 8 受付, 2005. 2. 14 受理)

\begin{abstract}
要 約 豚粪の堆肥化における消石灰添加が電気伝導度（EC）とミネラル溶出率に及ぼす影響につい て調べた. EC は消石灰添加率が高いほど低くなる傾向にあった。 4 週後の通気終了時における EC 測定 液のミネラル濃度は，Ca を除いて消石灰添加率が高いほど低くなった。一方，Caは添加率による差は 認められなかった。消石灰添加によってミネラル溶出率は $\mathrm{P}, \mathrm{Ca}, \mathrm{Mg}, \mathrm{K}, \mathrm{Na}$ のいずれも低下した. と くにP と Mg の低下率が大きかった．消石灰添加によってイオン交換水への K と Na の溶出率が低下す るのは交換性陽イオンとなるためと考えられた。 4 週後における堆肥の $0.3 \mathrm{~N}$ 塩酸抽出液のミネラル濃 度は，Ca 以外は消石灰添加率が高いほど低く，Ca は逆に高くなった. P , Ca， K, Na の溶出率は消石灰 添加率にかかわらずいずれも約 $90 \%$ 以上あったが，Mg だけが添加率が高くなるほど大きく低下した. 消石灰添加によって P と Mg の溶出率が大きく低下するのはリン酸マグネシウムアンモニウムによるも のではないと考えられた.
\end{abstract}

日本畜産学会報, 76 (2)：191-199, 2005

前報において高橋と柾木（2004）は，作業の都合など から豚糞を 7 日間嫌気貯蔵した場合に，堆肥化の基本で ある水分調整および通気を行っても温度上昇しないこと があり，そのような豚䔬に対して原物あたり $1.0 \%$ の消 石灰添加が堆肥化に有効であることを報告した。

農林省農事試験場（1932）は稲ワラや小麦桿の堆肥化 の際に，消石灰を水に溶いた石灰乳を用いることで酸性 に移行するのを防き，有機物分解を促進させる技術を報 告している. また, 藤田（1993）は下水污泥の堆肥化に 消石灰と塩化鉄を添加するとしている.さらに, 河田 （2000）は針葉樹バーク堆肥の製造に pH矯正の目的で 消石灰を用いるとしている.

このように堆肥化において消石灰添加は特殊な技術で はないにもかかわらず，消石灰のような塩基を添加する ことが製品堆肥の電気伝導度 (EC) などの品質に対する 影響を調べるような視点での研究はなされていない.わ ずかに, 畑中と窪田（2002）は牛䔬と杉樹皮の混合堆肥 に消石灰を添加すると無添加に比べ EC が低下したと報 告している.

中央畜産会（2000）によれば家畜糞堆肥の EC の基準 は 5 以下とされているが，家畜糞堆肥はもともとECが 高くなる傾向にあるため消石灰添加によって EC が上昇
することは堆肥の利用促進からもできるだけ避けたいと ころである.

そこで本研究では, 豚糞モミガラ堆肥における消石灰 添加時の EC への影響とその要因となるミネラルなどの 溶出率について検討することを目的とした。

\section{材料および方法}

\section{1. 材 料}

材料 1. 新鮮豚糞の消石灰添加堆肥化試験

高橋と柾木（2004）の試験 3 の新鮮豚䔬およびモミガ ラ混合物に対する消石灰添加試験の材料を用いた．新鮮 豚䔬およびモミガラ混合物に対し，消石灰を原物あたり $0 ， 0.5,1.0,1.5 \%$ 添加した試験区を設定した.

小型堆肥化装置（羽賀ら 1996）を用いて 4 週間の通気 を行った後に，さらに長期間の堆積期間中の成分変化も 調べるため（高橋 2004）に，ポリ広口ビンのロをわずか にあけて換気がわずかにある状態で通気開始から 12 力 月後まで実験室内において堆肥化試験を実施した。通気 終了後の試験期間中, 通気開始から 3 および 6 力月目に 切り返しを行い, 分析用試料を採取した。

材料 2. 7 日間の嫌気豚䔬の消石灰添加堆肥化試験

高橋と柾木（2004）の試験 4 の 7 日間の嫌気豚粪およ

現所属 : ${ }^{a}$ 石川県農業総合研究センター, 金沢市 920-3198

連絡者: 高橋正宏（fax:076-257-9152,e-mail : takando@pref.ishikawa.jp） 
びモミガラ混合物に対する消石灰添加試験の材料を用い た. 新鮮豚粸とモミガラ混合物および，7日間の嫌気貯 蔵豚粪（嫌気豚粪）とモミガラ混合物に対し，消石灰を 原物あたり無添加，1.0, 1.5\% 添加の試験区を設定した。 堆肥化試験は材料 1 と同様に 12 力月間実施した。

\section{2. 試験方法}

\section{試験 1. 消石灰添加による堆肥 EC の推移}

材料 1 および 2 の原料ならびに堆肥化過程において採 取した試料を $60^{\circ} \mathrm{C} て ゙ 48$ 時間乾燥後粉砕した. その後, 風乾試料を用いて $\mathrm{EC}$ を測定した。

\section{試験 2. EC 測定液のミネラル濃度および溶出率}

材料 1 の詰め込み時原料および 4 週後の通気終了時の 風乾試料を湿式灰化後, ミネラル含有率を測定した。ま た，同じ試料を用いてEC 測定液を濾紙（No.6）で濾過 し, 濾液を湿式灰化後ミネラル濃度を測定した。ミネラ ル成分はリン $(\mathrm{P})$, カルシウム $(\mathrm{Ca})$, マグネシウム $(\mathrm{Mg})$, カリウム $(\mathrm{K})$, ナトリウム $(\mathrm{Na})$ を調べた. 同じ 濾液を用いてアンモニア態窒素 $\left(\mathrm{NH}_{4}-\mathrm{N}\right)$ と塩素イオン $\left(\mathrm{Cl}^{-}\right)$および硫酸イオン $\left(\mathrm{SO}_{4}{ }^{2-}\right)$ も測定した.

試験 3. 酶酸アンモニウム抽出液中のミネラル濃度 および溶出率

試験堆肥中の交換性陽イオンを調べるために，材料 1 の原料および 4 週後の通気終了時の試料を用いて試験 2 のイオン交換水の代わりに $1 \mathrm{~N}$ 酶酸アンモ二ウム溶液に よって抽出して濾紙（No.6）で濾過し, 濾液を湿式灰化 後, ミネラルを測定した。ミネラル成分は $\mathrm{Ca}, \mathrm{Mg}, \mathrm{K}$, Naを調べた。

試験 4. 塩酸抽出液中のミネラル濃度および溶出率 試験堆肥中のリン酸マグネシウムアンモニウム (MAP) の存在を調べるために, MAP が pH 5 以下に溶解する （棚橋と矢野 2004）ことを利用して塩酸溶液中のミネラ
ル成分等を調べた。まず，試験堆肥を低 $\mathrm{pH}$ で溶解する ための条件を調べるために $0.1 \mathrm{~N}$ と $0.3 \mathrm{~N}$ の塩酸に溶解 し, pHおよびECを測定した。

さらに，材料 1 の原料および 4 週後の通気終了時の試 料を用いて試験 2 のイオン交換水の代わりに $0.3 \mathrm{~N}$ 塩酸 によって抽出して濾紙（No. 6）で濾過し，濾液を湿式灰 化後, 試験 2 と同じ項目のミネラル成分を調べた。また, 濾液を用いて $\mathrm{NH}_{4}-\mathrm{N}$ も測定した。

\section{3. 分析方法}

分析法は堆肥等有機物分析法（日本土壤協会 2000）に より，交換性陽イオンの抽出は土壤，水質および植物体 分析法（日本土壤協会 2001）に従って行った。 EC は, 風 乾試料を水または塩酸溶液を用いて $1: 10(\mathrm{w} / \mathrm{v})$ で測定 した。ミネラル成分は湿式灰化後，Pはバナドモリブデ 酸比色法, $\mathrm{Ca}, \mathrm{Mg}, \mathrm{K}, \mathrm{Na}$ は原子吸光光度法で測定し た. アンモ二ア態窒素は水蒸気蒸留法で測定した. $\mathrm{Cl}^{-}$ および $\mathrm{SO}_{4}{ }^{2-}$ はイオンクロマトグラフ法で測定した.

\section{結果}

\section{1. 消石灰添加による堆肥 EC の推移}

材料 1 の EC の推移を図 1 に, 材料 2 の EC の推移を 図 2 に示した. 材料 1 の詰め込み時には, 消石灰無添加 の EC が最も高く，1.5\%，1.0\%，0.5\%の順で高くなっ た。しかし， 2 週後にはその値は逆転して消石灰添加濃 度が高いほどEC が低くなり，12 カ月間の試験期間中同 様の傾向で推移した.

材料 2 の詰め込み時には，7 日間の嫌気豚䔬の消石灰 $1.5 \%, 1.0 \%$ ，無添加，新鮮豚䔬の順で，EC が高くなっ た. 温度上昇した嫌気豚糞の消石灰 $1.5 \%, 1.0 \%$ 添加の EC は新鮮豚粪に対し著しく低くなり, $1.5 \%$ 添加がもっ とも低い值となった。これ以降 12 力月間の試験期間中

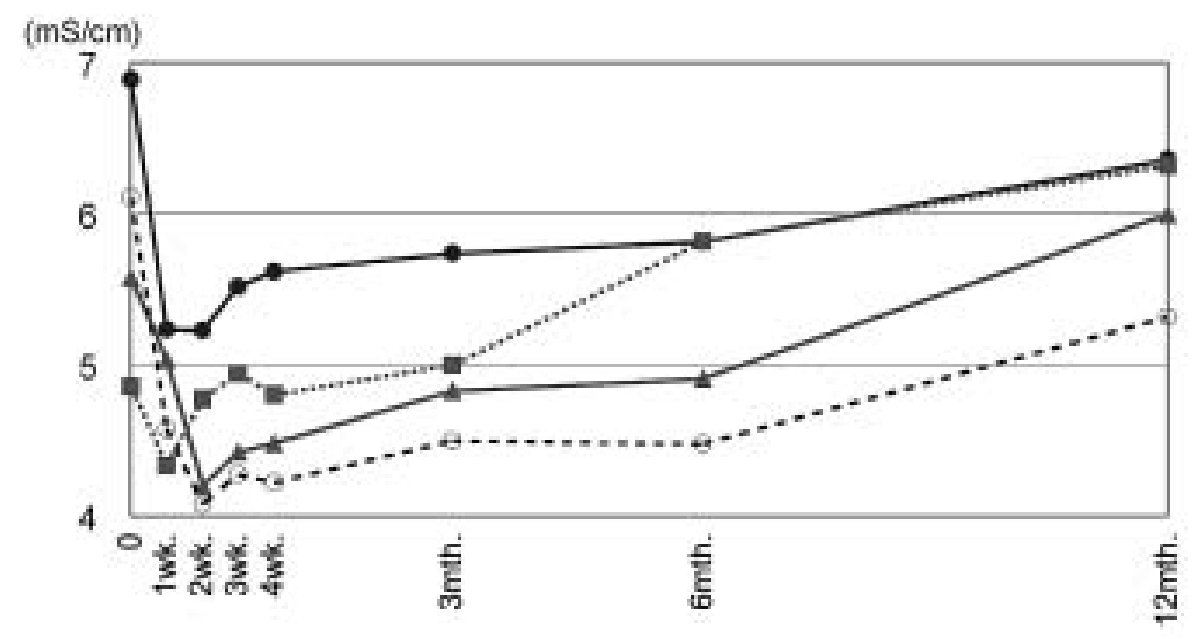

Fig. 1. Changes in EC of fresh swine manure compost with addition of slaked lime.

(-) No addition, (ם) $0.5 \%$ Slaked lime addition,

(A) $1.0 \%$ Slaked lime addition, $(\bigcirc)$ 1.5\% Slaked lime addition. 


\section{消石灰添加堆肥の $E C$ への影響}

を通じて同様の傾向で推移した。

\section{EC 測定液のミネラル濃度および溶出率}

堆肥中のミネラル成分組成を表 1 に示した。詰め込み 時および 4 週後で $\mathrm{Ca}$ 含有率は消石灰添加率が高くなる ほど高くなった。逆にその他の成分は Ca 増加による相
対的濃度が低下した。いずれの成分も有機物分解によっ て通気終了時には詰め込み時に比べ高くなった。

$\mathrm{EC}$ 測定溶液中のミネラル濃度, $\mathrm{NH}_{4}-\mathrm{N}, \mathrm{Cl}^{-}$および $\mathrm{SO}_{4}{ }^{2-}$ 濃度を表 2 に示した。詰め込み時には消石灰添加 率が高くなるほどCa は増加したが，逆にそれ以外の成

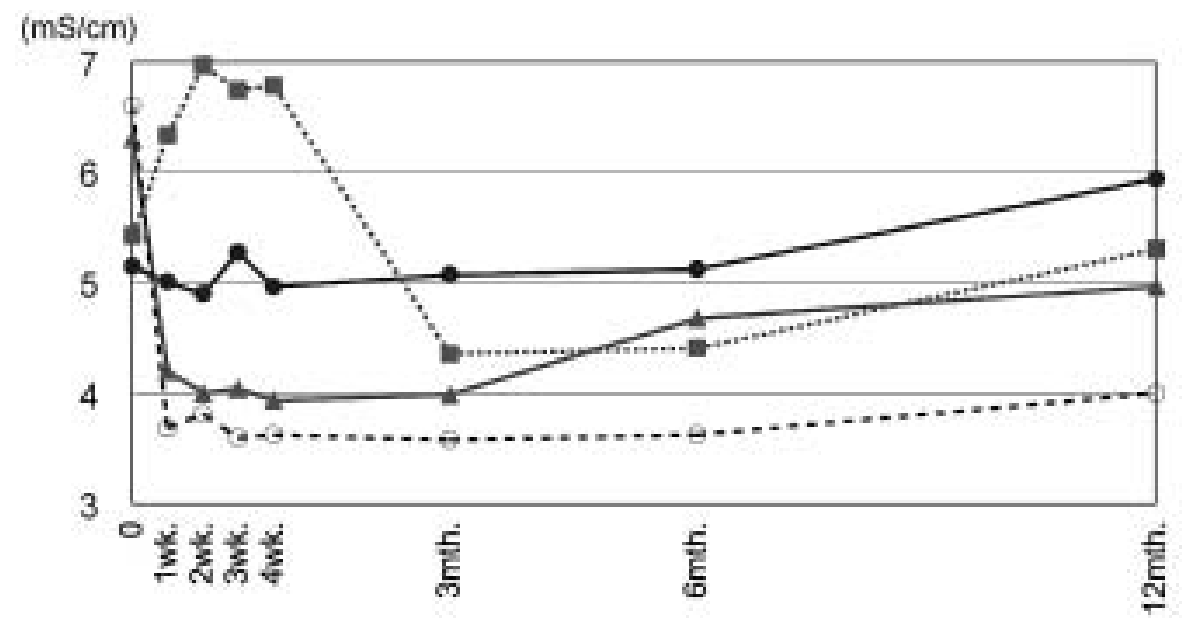

Fig. 2. Changes in EC of swine manure compost after 7 days of anaerobic storage.

(O) Fresh feces, (ם) Anaerobic feces,

(A) Anaerobic feces added 1.0\% Slaked lime, (○) Anaerobic feces added 1.5\% Slaked lime.

Table 1. Changes in mineral constituents of swine manure compost with addition of slaked lime

$(\% / \mathrm{DM})$

\begin{tabular}{ccccccccccc}
\hline \hline & \multicolumn{3}{c}{0 day } & & \multicolumn{4}{c}{4 weeks } \\
\cline { 2 - 6 } \cline { 8 - 10 } & $0.0 \%$ & $0.5 \%$ & $1.0 \%$ & $1.5 \%$ & & $0.0 \%$ & $0.5 \%$ & $1.0 \%$ & $1.5 \%$ \\
\hline $\mathrm{P}$ & 1.23 & 1.17 & 1.10 & 1.08 & & 2.00 & 1.94 & 1.91 & 1.91 \\
$\mathrm{Ca}$ & 1.55 & 2.44 & 3.11 & 3.86 & & 2.38 & 3.89 & 5.20 & 6.69 \\
$\mathrm{Mg}$ & 0.68 & 0.61 & 0.58 & 0.60 & & 1.03 & 0.97 & 0.91 & 0.88 \\
$\mathrm{~K}$ & 1.63 & 1.57 & 1.52 & 1.55 & & 2.53 & 2.38 & 2.40 & 2.38 \\
$\mathrm{Na}$ & 0.31 & 0.29 & 0.27 & 0.27 & & 0.44 & 0.45 & 0.42 & 0.42 \\
\hline
\end{tabular}

Table 2. Changes in chemical constituents of manure extracts in distilled water

(ppm)

\begin{tabular}{|c|c|c|c|c|c|c|c|c|}
\hline & \multicolumn{4}{|c|}{0 day } & \multicolumn{4}{|c|}{4 weeks } \\
\hline & $0.0 \%$ & $0.5 \%$ & $1.0 \%$ & $1.5 \%$ & $0.0 \%$ & $0.5 \%$ & $1.0 \%$ & $1.5 \%$ \\
\hline$P$ & 446 & 161 & 60 & 44 & 540 & 228 & 168 & 97 \\
\hline $\mathrm{Ca}$ & 100 & 117 & 450 & 776 & 59 & 55 & 57 & 58 \\
\hline $\mathrm{Mg}$ & 347 & 180 & 151 & 104 & 195 & 58 & 30 & 17 \\
\hline K & 1,440 & 1,209 & 1,271 & 1,275 & 1,843 & 1,550 & 1,558 & 1,545 \\
\hline $\mathrm{Na}$ & 239 & 199 & 212 & 207 & 329 & 263 & 253 & 234 \\
\hline $\mathrm{NH}_{4}-\mathrm{N}$ & 2,067 & 333 & 273 & 227 & 181 & 190 & 128 & 120 \\
\hline $\mathrm{Cl}^{-}$ & 361 & 360 & 349 & 343 & 577 & 571 & 542 & 542 \\
\hline $\mathrm{SO}_{4}{ }^{2-}$ & 266 & 256 & 247 & 246 & 259 & 282 & 191 & 247 \\
\hline
\end{tabular}


分は低下し，とくにP, Mg および $\mathrm{NH}_{4}-\mathrm{N}$ は大きく減少 した.

4 週後では消石灰添加率が高くなるほど Ca 以外の成 分は減少し, P と Mgは大きく減少した. Caは添加率に かかわらずほぼ一定で低い値を示した。詰め込み時に比 べ通気終了時では $\mathrm{Ca}, \mathrm{Mg}, \mathrm{NH}_{4}-\mathrm{N}$ および $\mathrm{Cl}^{-}$の濃度が低 下したが，P，K， Na は逆に増加した． $\mathrm{SO}_{4}{ }^{2-}$ はとくに傾 向はなかった。硝酸態窒素は前報（高橋と柾木 2004）で 生試料を用いて測定したがほとんど検出されなかった。

図 3 に表 1 と 2 から求めたミネラル溶出率を示した. 詰め込み時では Ca は消石灰添加率が高くなるほど高く なったが, $1.5 \%$ 添加でも $20 \%$ 程度と低い值であった.

$\mathrm{K}, \mathrm{Na}$ は $80 \%$ 前後と比較的高い溶出率であった. $\mathrm{P}, \mathrm{Mg}$ はもともと K, Na よりも溶出率は低かったが, 消石灰添 加率が高くなるほど低下した.

4 週後では詰め込み時に比べいずれの成分も溶出率が 低下した. K, Na は消石灰無添加でも $70 \%$ あまりで消石 灰添加によって $60 \%$ 前後に低下した.P, Mg は消石灰 添加によって溶出率は大きく低下した。Ca も溶出率は 低下したが無添加でも $2.5 \%$ と非常に低い值であった。
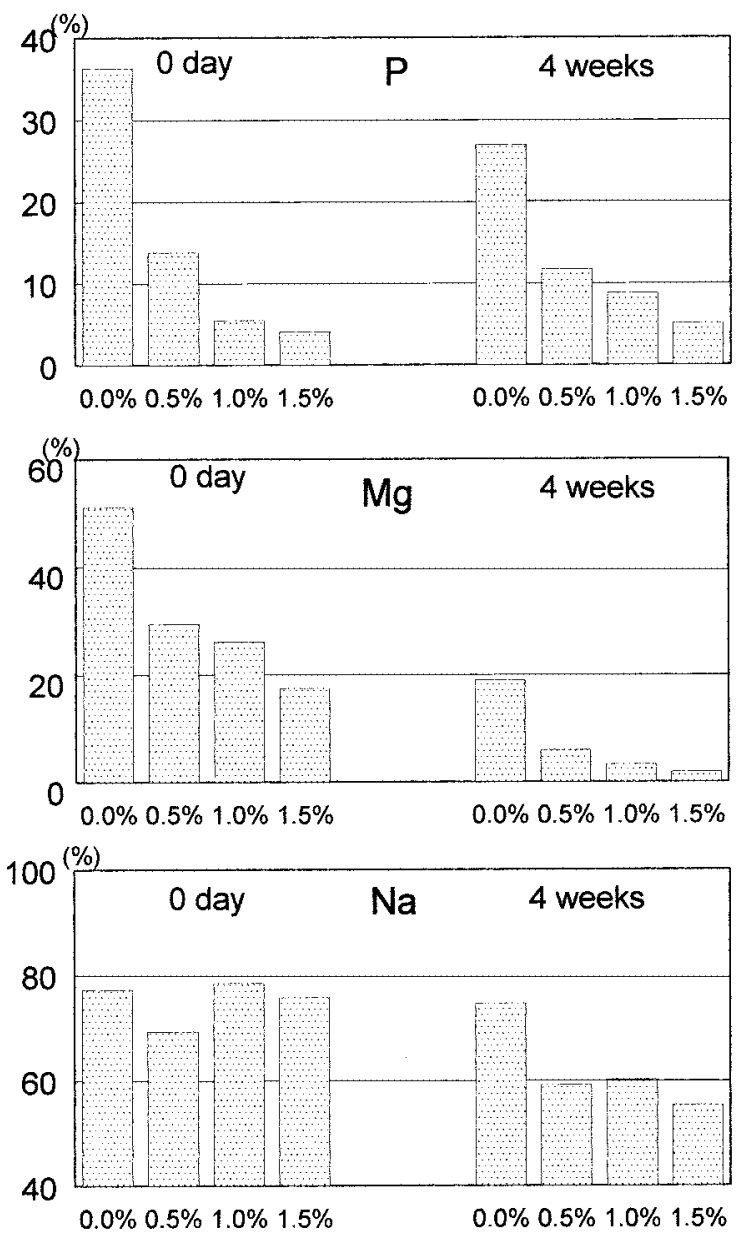

3. 酶酸アンモニウム抽出液中のミネラル濃度および 溶出率

試験堆肥中の交換性陽イオンを調べるために，試験 2 のイオン交換水の代わりに $1 \mathrm{~N}$ 酶酸アンモニウムを用い て抽出したミネラル濃度を表了に示した。詰め込み時で は Ca は消石灰添加率が高くなるほど高くなったが，他 の成分は逆に低下し, Mg の低下が大きかった. 4 週後で は Ca にやや変動があるものの各成分は添加率にかかわ らずほぼ差のない值を示していた。

図 4 に表 1 と 3 から求めたミネラル溶出率を水溶性塩 基と交換性塩基と分けて示した. Ca は詰め込み時に消 石灰添加率が高くなるほど溶出率は高くなったが，交換 性 Ca は無添加で低くなった. 4 週後には消石灰添加率 が高くなるほど交換性 Ca が低下した.Mgは詰め込み 時に無添加の溶出率は高くなったが交換性 Mgは逆に消 石灰添加率が高くなるほど高くなった。 4 週後には交換 性 Mg が無添加で負の値となり, 消石灰添加率が高くな るほど高くなった. K は詰め込み時と 4 週後でいずれの 区も溶出率が 100\% 近くと高くなったが，4週後には交 換性 K の割合が増加し，消石灰添加で著しかった. Na
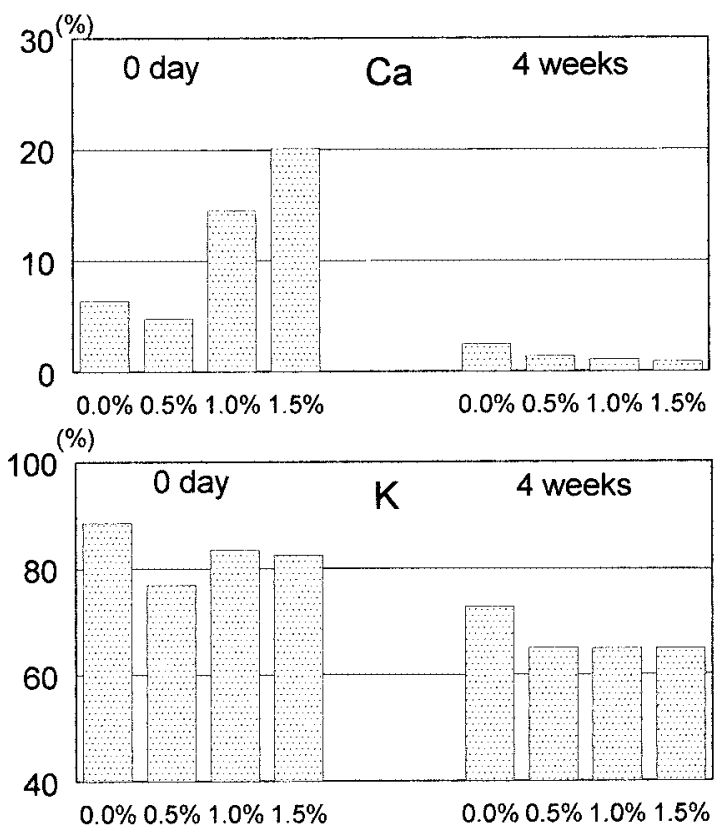

Fig. 3. Changes in mineral extraction rates of the manure extracts in distilled water. 


\section{消石灰添加堆肥の $\mathrm{EC}$ への影響}

Table 3. Changes in chemical constituents of manure extracts in $1 \mathrm{~N} \mathrm{CH}_{3} \mathrm{COONH}$

(ppm)

\begin{tabular}{|c|c|c|c|c|c|c|c|c|}
\hline & \multicolumn{4}{|c|}{0 day } & \multicolumn{4}{|c|}{4 weeks } \\
\hline & $0.0 \%$ & $0.5 \%$ & $1.0 \%$ & $1.5 \%$ & $0.0 \%$ & $0.5 \%$ & $1.0 \%$ & $1.5 \%$ \\
\hline $\mathrm{Ca}$ & 296 & 718 & 1,232 & 1,606 & 503 & 702 & 565 & 568 \\
\hline $\mathrm{Mg}$ & 331 & 215 & 198 & 192 & 112 & 88 & 106 & 117 \\
\hline K & 1,578 & 1,532 & 1,478 & 1,456 & 2,434 & 2,449 & 2,394 & 2,345 \\
\hline $\mathrm{Na}$ & 256 & 241 & 244 & 232 & 395 & 394 & 373 & 346 \\
\hline
\end{tabular}
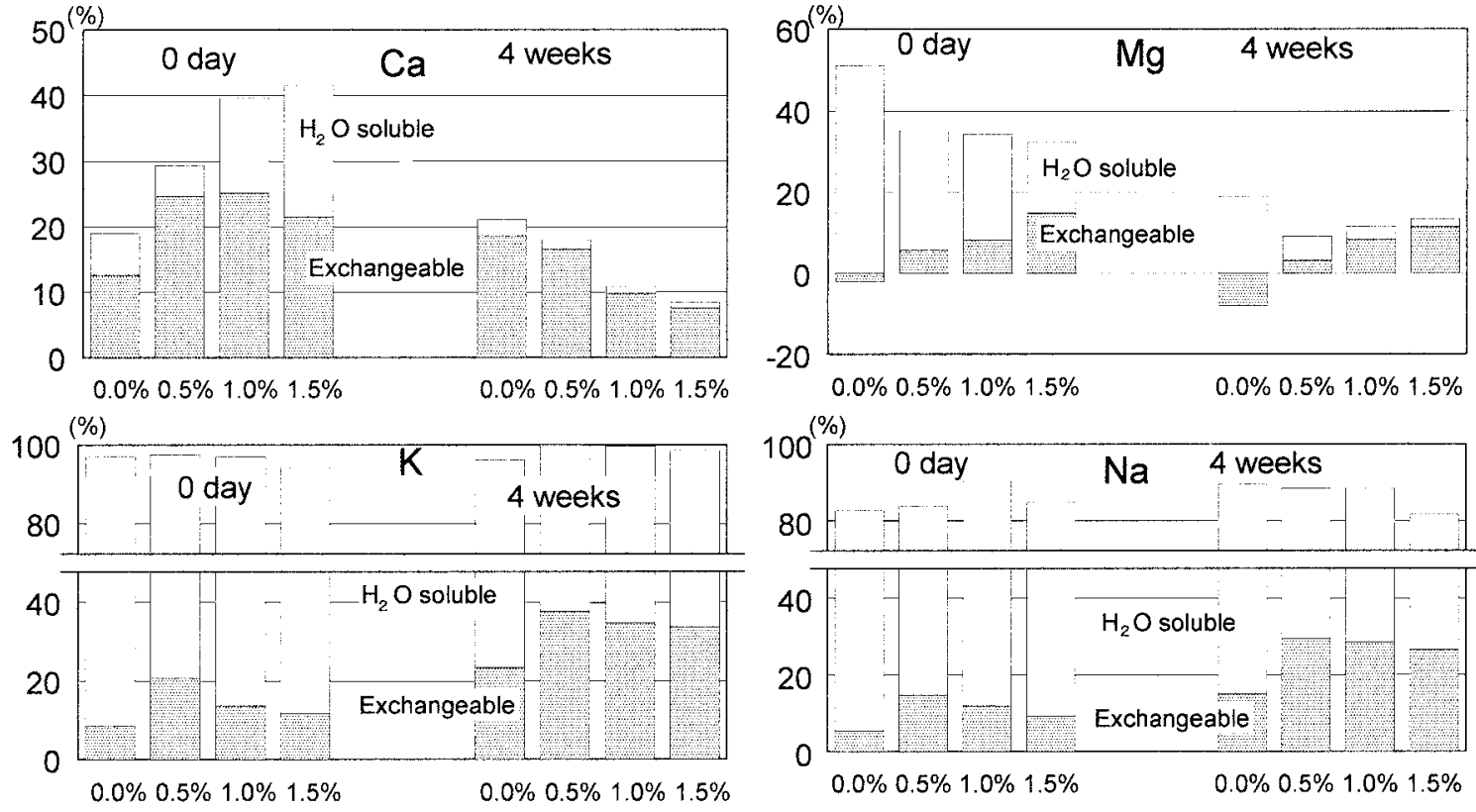

Fig. 4. Changes in mineral extraction rates of manure extracts in $1 \mathrm{~N} \mathrm{CH}_{3} \mathrm{COONH}_{4}$.

の溶出率は 80 90\% とKよりも低いものの同じ傾向を 示し，消石灰添加で交換性 Na の割合が高くなった。

\section{4. 塩酸抽出液中のミネラル濃度および溶出率}

試験 2 でP と Mg の溶出率が消石灰添加によって大き く減少したことから, $\mathrm{P}, \mathrm{Mg}$ と $\mathrm{NH}_{4} \mathrm{~N}$ を構成要素とする MAP が消石灰添加によって生成されるかについて調べ た.MAP は酸に溶解する（鈴木 2002 ; 棚橋と矢野 2004) ことから，酸性条件下で堆肥を抽出した場合の $\mathrm{P}, \mathrm{Mg}$ と $\mathrm{NH}_{4}-\mathrm{N}$ の濃度の上昇の程度によって MAP の存在を調 ベた。詰め込み時および 4 週後の堆肥を塩酸溶液で $E C$ 測定溶液のように振とうして pH および EC を測定した 結果を表 4 に示した。

$0.1 \mathrm{~N}$ 塩酸では堆肥溶液の $\mathrm{pH}$ は消石灰添加率が高く なるほど上昇して 5 以上となった。 EC は詰め込み時に は消石灰添加率が高くなるほど高かったが，通気終了時 には逆に低くなった. $0.3 \mathrm{~N}$ 塩酸では堆肥溶液の $\mathrm{pH}$ は消 石灰添加率が高くても2.2 で MAPを十分溶解すること
Table 4. Changes in $\mathrm{EC}$ and $\mathrm{pH}$ of manure extracts in $\mathrm{HCl}$ solution

\begin{tabular}{|c|c|c|c|c|c|}
\hline & \multirow{2}{*}{$\begin{array}{l}\text { Slaked } \\
\text { lime } \\
\text { addition }\end{array}$} & \multicolumn{2}{|c|}{$0.1 \mathrm{~N} \mathrm{HCl}$} & \multicolumn{2}{|c|}{$0.3 \mathrm{~N} \mathrm{HCl}$} \\
\hline & & 0 day & 4 weeks & 0 day & 4 weeks \\
\hline \multirow{5}{*}{$\begin{array}{c}E C \\
(\mathrm{mS} / \mathrm{cm})\end{array}$} & Solution & 40.4 & & 110 & \\
\hline & $0.0 \%$ & 12.8 & 14.3 & 63.9 & 51.9 \\
\hline & $0.5 \%$ & 12.7 & 13.9 & 60.2 & 41.8 \\
\hline & $1.0 \%$ & 13.2 & 13.4 & 51.6 & 34.2 \\
\hline & $1.5 \%$ & 13.7 & 13.3 & 42.4 & 29.9 \\
\hline \multirow{5}{*}{$\mathrm{pH}$} & Solution & 1.1 & & 0.7 & \\
\hline & $0.0 \%$ & 3.5 & 4.7 & 0.9 & 1.1 \\
\hline & $0.5 \%$ & 4.2 & 5.5 & 0.9 & 1.2 \\
\hline & $1.0 \%$ & 4.7 & 5.6 & 1.0 & 1.5 \\
\hline & $1.5 \%$ & 5.1 & 5.8 & 1.2 & 2.2 \\
\hline
\end{tabular}


が可能な pH5（棚橋と矢野 2004）よりも低くなった. EC は詰め込み時, 通気終了時ともに消石灰添加率が高くな るほど低くなった。

表 5 に $0.3 \mathrm{~N}$ 塩酸による堆肥抽出液のミネラルおよび $\mathrm{NH}_{4}-\mathrm{N}$ 濃度を示した。詰め込み時の $\mathrm{Ca}$ 濃度は消石灰添 加率が高いほど高くなったが，他の成分は逆に低下し た. 4 週後では $\mathrm{NH}_{4}-\mathrm{N}$ を除いて詰め込み時より濃度が高
くなった，消石灰添加率が高くなるほよ゙ Ca は濃度が高 くなったが，他の成分は逆に低下し， Mg と $\mathrm{NH}_{4}-\mathrm{N}$ が特 にその傾向が強かった。

図 5 に表 1 と 5 から求めた $0.3 \mathrm{~N}$ 塩酸によるミネラル 溶出率を水溶性と酸可溶性に分けて示した。Pは詰め込 み時で消石灰添加率が高くなるほど水溶性 $\mathrm{P}$ が低く, 酸 可溶性 $\mathrm{P}$ が高くなり，合計量は $80 \%$ とほぼ同じとなっ

Table 5. Changes in chemical constituents of manure extracts in $0.3 \mathrm{~N} \mathrm{HCl}$

\begin{tabular}{|c|c|c|c|c|c|c|c|c|}
\hline & \multicolumn{4}{|c|}{0 day } & \multicolumn{4}{|c|}{4 weeks } \\
\hline & $0.0 \%$ & $0.5 \%$ & $1.0 \%$ & $1.5 \%$ & $0.0 \%$ & $0.5 \%$ & $1.0 \%$ & $1.5 \%$ \\
\hline$P$ & 1,029 & 953 & 923 & 818 & 1,778 & 1,749 & 1,716 & 1,686 \\
\hline $\mathrm{Ca}$ & 1,442 & 2,296 & 3,223 & 3,893 & 2,290 & 3,763 & 5,221 & 6,456 \\
\hline $\mathrm{Mg}$ & 587 & 558 & 547 & 547 & 927 & 840 & 629 & 542 \\
\hline K & 1,579 & 1,533 & 1,500 & 1,471 & 2,406 & 2,381 & 2,317 & 2,182 \\
\hline $\mathrm{Na}$ & 262 & 251 & 244 & 244 & 433 & 427 & 396 & 392 \\
\hline $\mathrm{NH}_{4}-\mathrm{N}$ & 2,122 & 525 & 355 & 391 & 502 & 277 & 210 & 215 \\
\hline
\end{tabular}
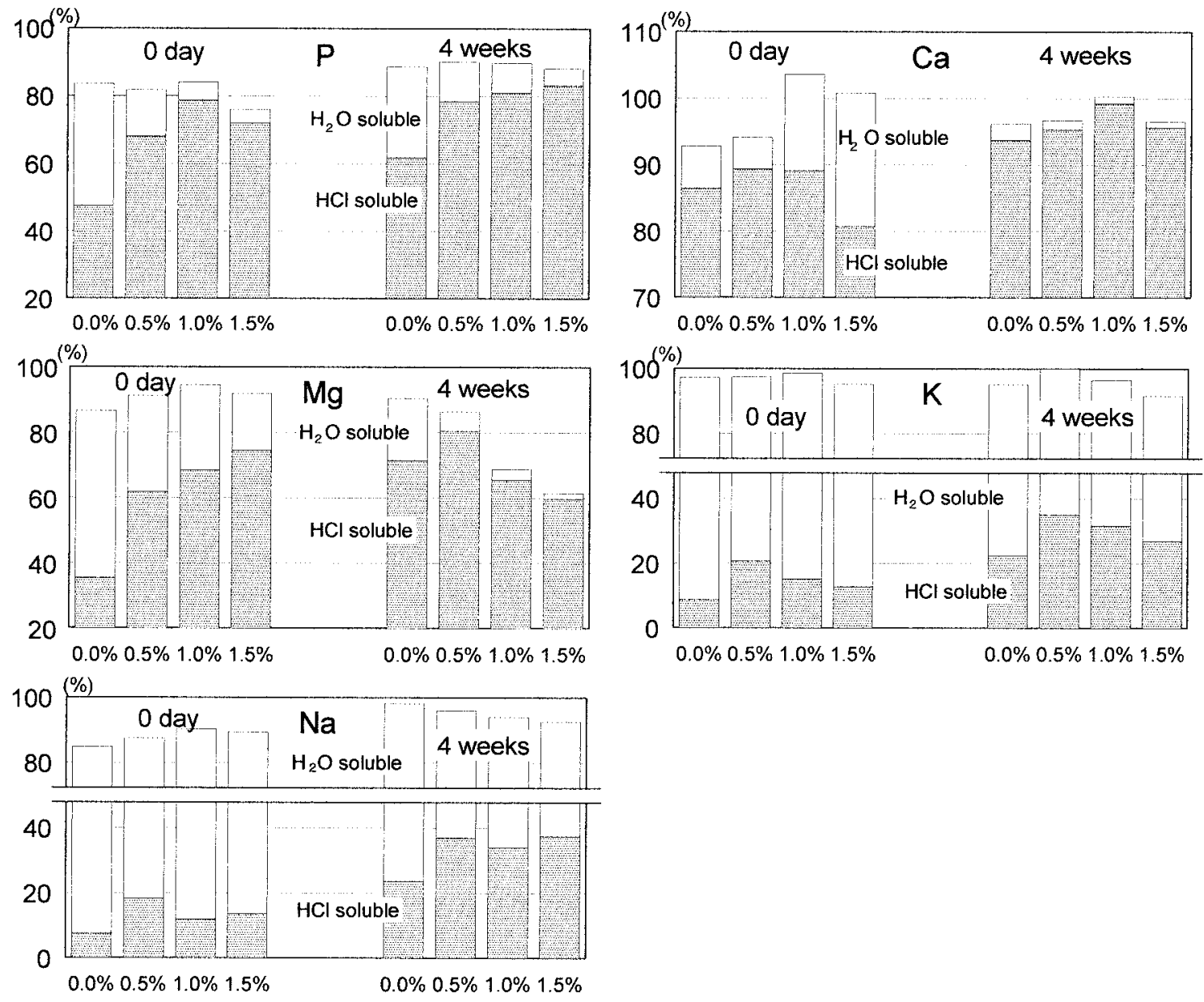

Fig. 5. Changes in mineral extraction rates of the manure extracts in $0.3 \mathrm{~N} \mathrm{HCl}$. 
た. 4 週後には酸可溶性 P の割合が一層高くなり, 消石 灰添加率が高くなるほどその傾向は顕著になった，水溶 性・酸可溶性の合計量は消石灰添加率にかかわらず 90\% と詰め込み時より高くなった. Caは詰め込み時の 消石灰添加率 $1.0 \%, 1.5 \%$ で水溶性 Ca がやや多いが， 4 週後には水溶性はほとんどなくなりほぼ酸可溶性となっ た. 水溶性・酸可溶性の合計量は消石灰添加率にかかわ らず 95\% 以上と高くなった. Mg は詰め込み時で消石灰 添加率が高いほど酸可溶性 $\mathrm{Mg}$ が多く, 逆に水溶性 Mg が低くなり，その合計量は $80 \%$ 以上でほぼ差のない値 であった．しかし，4 週後では消石灰添加率が高くなる ほど酸可溶性 Mg も低下し, 酸不溶 Mg が増加した.K は詰め込み時と 4 週後でいずれの区も溶出率が $100 \%$ 近 くと高くなったが，4週後には酸可溶性Kの割合が増加 し, 消石灰添加で著しかった. Na の詰め込み時の溶出率 は 80 90\% とKよりも低いものの同じ傾向を示し, 消 石灰添加で酸可溶性 Na の割合が高くなった。

図 6 に，表 2 と 5 の差つまり水不溶かつ酸可溶のP, $\mathrm{Mg}, \mathrm{NH}_{4}-\mathrm{N}$ のモル濃度を示した. 詰め込み時には $\mathrm{P}>\mathrm{Mg}$ $>\mathrm{NH}_{4}-\mathrm{N}$ の順で酸溶液によって多く溶出していたが, 通 気終了時では各成分の差はさらに大きくなった。Pは消 石灰添加率が高くなるほど多く溶出したが, Mg と $\mathrm{NH}_{4}-\mathrm{N}$ の溶出率は逆に低下した。低 $\mathrm{pH}$ になって MAP が溶解しているとすれば，その量はもっとも少ない $\mathrm{NH}_{4}-\mathrm{N}$ の溶解量以下であった。

\section{考察}

消石灰を添加して堆肥化を行うとECは消石灰添加 率が高いほど無添加に比べ低くなったが, 畑中と窪田 （2002）は牛糞と杉樹皮の堆肥でも同様な結果を報告し ていることから，本試験で使用した豚糞モミガラ堆肥に 特に限定した傾向ではないと考えられた。 なお, 図 $2 て ゙$ 嫌気豚粪消石灰無添加の EC が 4 週後までもっとも高く 推移するのは，前報（高橋と柾木 2004）に示したように 有機酸が大幅に増加して風乾物にも残存していたためと
考えられた。

EC は水中に溶けているイオン量と各イオンの電気を 運ぶ速さによって支配される（藤原ら 1998）。本試験で 測定した堆肥の $E C$ 測定液中の個々のイオンの $E C へ の$ 寄与率は不明であるが, 試験結果から消石灰添加による EC 低下の主な要因として以下のことが考えられる.

（1）添加した消石灰は堆肥化によって水への溶出率の 低い化合物となるが, 添加率が高いほどKおよび $\mathrm{Na}$ のような溶出率の高いミネラル成分の含有率 が低下した。

（2）消石灰添加によってKおよび Na のような溶出率 の高いミネラルの一部が水溶性から交換性に変 わって水への溶出率が低下した.

（3）消石灰添加によってPおよび Mg の一部が水溶性 から酸可溶性に変わって水への溶出率が低下し た.さらに, Mgの一部は酸不溶性となった。

（4）消石灰添加によって $\mathrm{pH}$ が上昇して $\mathrm{NH}_{4}-\mathrm{N}$ が堆肥 化過程においてより多くアンモニアガスとして揮 散して（高橋と柾木 2004）低下した.

$P$ および Mg の溶出率が大きく低下したことと， 前報 （高橋と柾木 2004）で示したようにいずれの堆肥も $\mathrm{pH}$ は 8.8 程度のアルカリ性であったため, 堆肥化過程で MAPを生成した可能性（棚橋と矢野 2004）が考えられ た.MAPが多く存在しているならば酸性条件下でP, $\mathrm{Mg}, \mathrm{NH}_{4}-\mathrm{N}$ が当量で溶解すると考えられる。しかし，実 際には P のみが多く溶解し, $\mathrm{Mg}$ や $\mathrm{NH}_{4}-\mathrm{N}$ がそれほど増 加していないことから, 消石灰添加によって溶出率が低 下したMgはMAP生成によるものは最大でも水不溶・ 酸可溶の $\mathrm{NH}_{4}-\mathrm{N}$ に相当する濃度だけで大半は MAPによ るもでないと考えられた。

$\mathrm{P}$ と Ca は酸でかなり溶解していることからヒドロキ シアパタイト $\left[\mathrm{Ca}_{10}(\mathrm{OH})_{2}\left(\mathrm{PO}_{4}\right)_{6}\right]$ (鈴木 2002) のよう な化合物となっている可能性が考えられた. Mgについ てもアパタイト族（長倉ら 1998）の可能性も考えられる

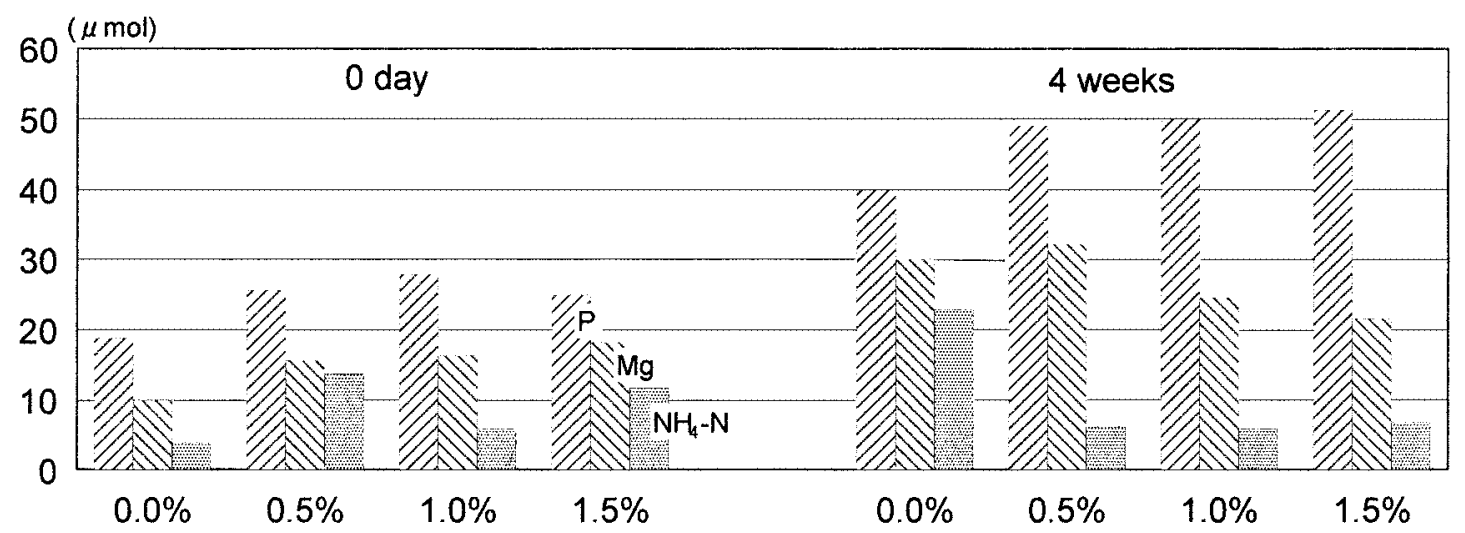

Fig. 6. Changes in components of water-insoluble and $0.3 \mathrm{~N}-\mathrm{HCl}$-soluble fractions of the manure. 
が, 酸に不溶な $\mathrm{P}$ は少なく, 消石灰添加率が高くても酸 不溶の割合は Mg のようには変化しないことから対とな るPが不足すると考えられ，詳細は不明であった。

\section{謝辞}

本研究の実施にあたり, 懇切なる指導を賜った上, MAP 標本を快く提供して頂きました独立行政法人農 業・生物系特定産業技術研究機構畜産草地研究所鈴木一 好環境浄化研究室長に深く感謝の意を表します。また， 陰イオンの分析に協力を頂いた石川県工業試験場技師藤 島夕喜代さんに，分析全般に献身的な協力をいただいた 石川県畜産総合セン夕一飼料環境科松本秀代さんに深く 感謝の意を表します.

\section{文献}

（社）中央畜産会. 2000. 堆肥化施設設計マニュアル．第 2 版. 221-230.（社)中央畜産会. 東京.

藤原俊六郎・安西徹郎・小川吉雄・加藤哲郎。1 1998. 新版土壌 肥料用語事典. 294. (社)農村漁村文化協会. 東京.

藤田賢二. 1993. コンポス卜化技術廃棄物有効利用のテクノ ロジー. 67-68. 技報堂出版. 東京.

羽賀清典・長田 隆・ 田中康男・黒田和孝・花島 大. 1996.
堆肥化実験装置. 特許出願番号平成 8 年特許出願第 235967 号.

畑中博英・窪田泰之. 2002. 未利用有機物資源の堆肥化亡利用 技術. 石川県農業総合研究セン夕一研究報告, $24: 28-32$.

河田 弘. 2000. バーク (樹皮) 堆肥製造・利用の理論と実 際. 70-71. 博友社. 東京.

長倉三郎・井口洋夫・江沢 洋・岩村 秀・佐藤文隆・久保亮 五. 1998. 岩波理化学辞典. 第 5 版. 27-28. 岩波書店. 東 京.

（財）日本土壤協会. 2000. 堆肥等有機物分析法. 18-42. (財) 日 本土畩協会. 東京.

(財) 日本土壤協会. 2001. 土壤, 水質及び植物体分析法. 52-59. (財) 日本土壤協会. 東京.

農林省農事試験場. 1932. 促成堆肥製造法要綱. 1-12. 農林省農 事試験場. 東京.

鈴木一好. 2002. 結晶化法による豚舎污水中リンの除去及び回 収. 日本養豚学会誌, 39: 101-111.

高橋正宏. 2004. 豚粪モミガラ堆肥への消石灰添加がもたらす 有機物分解促進効果とデタージェント分析による効果の検 証. 日本畜産学会報, $75:$ 587-598.

高橋正宏・柾木茂彦. 2004. 嫌気貯蔵豚粪の堆肥化と消石灰の 添加効果. 日本畜産学会報, $75: 429-440$.

棚橋寿彦・矢野秀治. 2004. 家畜ふん堆肥中の常法では抽出さ れないアンモニア態窒素の存在. 平成 15 年度関東東海北 陸農業研究成果情報III, 174-175. 


\title{
Influence of the Addition of Slaked Lime to Swine Manure on Electrical Conductivity and Mineral Extraction Rate
}

\author{
Masahiro TAKAHASHI and Hideyuki UMEMOTO'1 \\ Ishikawa Prefectual Livestock Research Center, Oshimizu-machi, Ishikawa-ken 929-1325, Japan \\ ${ }^{1}$ Ishikawa Agricultural Research Center, Kanazawa-shi 920-3198, Japan \\ Corresponding : Masahiro TAKAHASHI (fax : +81 (0) 76-257-9152, e-mail : takando@pref.ishikawa.jp) \\ This study was intended to examine the influence of the addition of slaked lime on electrical conductivity \\ (EC) and the mineral extraction rate of swine manure compost. Results showed that the larger the slaked lime \\ addition rate was, the lower the EC tended to become. Four weeks after slaked lime addition and at the end \\ of aeration, the larger the slaked lime addition rate was, the lower the concentrations of minerals in the \\ manure extract in distilled water became, except for the calcium concentration, which did not differ regardless \\ of the addition rate. Extraction rates of phosphorus, calcium, magnesium, potassium, and sodium decreased \\ according to the addition of slaked lime ; especially those of phosphorus and magnesium decreased sharply. \\ The increase of exchangeable potassium and sodium can explain the decrease of their extraction rates in \\ water by slaked lime addition. As for the manure extract in $0.3 \mathrm{~N} \mathrm{HCl}$ after the four-week period, the more \\ slaked lime was added, the higher the calcium concentration became. Conversely, concentrations of \\ phosphorus, magnesium, potassium, and sodium decreased as more slaked lime was added. Irrespective of \\ the slaked lime addition rate, extraction rates of phosphorus, calcium, potassium, and sodium were \\ approximately over $90 \%$. Nevertheless, the magnesium concentration decreased more along with the \\ increase of the slaked lime addition rate. Generation of magnesium ammonium phosphate could not explain \\ the sharply decreased extraction rates of phosphorus and magnesium that resulted from slaked lime addition. \\ Nihon Chikusan Gakkaiho, 76 (2) : 191-199, 2005
}

Key words : Slaked lime, Composting, Electoric conductivity, Mineral extract 